\title{
Juridical Analysis of The Effectiveness of Termination of Prosecutions Based On Restorative Justice
}

\author{
Oki Bogitama*) and Rakhmat Bowo Suharto**) \\ *) Banyumas District Prosecutor, E-mail: okibogitama@gmail.com \\ ${ }^{* *}$ Faculty of Law, Universitas Islam Sultan Agung Semarang
}

\begin{abstract}
The purpose of this research is to find out and analyze the effectiveness of stopping prosecutions based on restorative justice. To find out and analyze the process of discontinuing prosecution for termination based on restorative justice in terms of the principles of restorative justice. The approach method used in this research is a sociological juridical method (Sociological Research).Based on the results of this study it was concluded that effectiveness of the termination of prosecution based on Restorative Justice is carried out by taking into account the interests of the victims and other protected legal interests; avoidance of negative stigma; avoidance of retaliation; community response and harmony; and propriety, decency, and public order. The process of discontinuing prosecution based on restorative justice has met the requirements of the principle of restorative justice, namely that the Public Prosecutor offers peace efforts to Victims and Suspects. The Public Prosecutor shall summon the Victim legally and appropriately by stating the reason for the summons. In the event that it is deemed necessary, peace efforts may involve the families of the Victim/Suspect, community leaders or representatives, and other related parties. The Public Prosecutor shall notify the aims and objectives as well as the rights and obligations of the Victims and Suspects in peace efforts, including the right to refuse peace efforts. In the event that the peace effort is accepted by the Victim and the Suspect, the peace process will be continued.
\end{abstract}

Keywords: Effectiveness; Prosecution; Restorative Justice.

\section{Introduction}

Indonesia is a state of law, all of which are regulated by law. Regulations governing violations and crimes committed by each person are regulated in criminal law. The criminal justice system in Indonesia is in the form of pre-trial, adjudication and post-trial. Handling a criminal case of pre-judgment begins with an investigation to determine the suspect with sufficient initial evidence then the next step is the investigator delegates the suspect and evidence after going through the research process the case file is declared complete by the Public Prosecutor because the Public Prosecutor considers the suspect's actions to meet criminal elements. After that, the case files and suspects were transferred by the Public Prosecutor to the local District Court. In the implementation of the case handling process, The Public Prosecutor has the authority to stop a criminal case as regulated in the Criminal Procedure Code in particular Article 140 Paragraph (2) Letter (a) "In the event that the public prosecutor decides to stop the prosecution because there is not enough evidence or the incident turns out to be does not constitute a criminal act or the case is closed for the sake of law, the public prosecutor shall include this in a decree". The termination of prosecution by the 
Public Prosecutor based on Article 140 Paragraph (2) of the Criminal Procedure Code because the first case did not have sufficient evidence, the second incident was not a crime and the third case was closed for the sake of law the public prosecutor shall include this in a decree". The termination of prosecution by the Public Prosecutor based on Article 140 Paragraph (2) of the Criminal Procedure Code because the first case did not have sufficient evidence, the two events were not criminal acts and the third case was closed for the sake of law the public prosecutor shall include this in a decree". The termination of prosecution by the Public Prosecutor based on Article 140 Paragraph (2) of the Criminal Procedure Code because the first case did not have sufficient evidence, the two events were not criminal acts and the third case was closed for the sake of law.

Gustav Radbruch who argues that the law in its purpose needs to be oriented to three things, 1). Legal certainty, 2). Justice, 3). Usefulness (doelmatigheid) ${ }^{1}$. According to Radbruch, legal certainty is the main guide to the law, so that the law becomes positive, in the sense that it applies with certainty. The law must be obeyed, thus the law is truly positive. ${ }^{2}$ The law must have certainty, for that the law must be in the form of a written regulation. It is very important to understand that the Act cannot exhaust the law, because although the legal rules are formulated through the texts in the Law, the formulation of the text cannot fully accommodate the content and intent of the legal rules. ${ }^{3}$ The more laws meet the requirements of "correct regulations", which eliminate as much uncertainty as possible, the more precise and sharp the legal regulations, the more pressing justice will be. That is the meaning of summum ius, summa iniura, or more often heard with the expression that the highest justice is the highest injustice. ${ }^{4}$ The process of law enforcement can occur in a conflicting dilemma between the three elements of the above legal objectives, with prioritizing "legal certainty" then there is a possibility that other elements are ignored or sacrificed.

In the tradition of the prosecution doctrine, the principle of dominus litis is known. According to RM Surachman, in several countries such as Japan, the Netherlands and France, the prosecution authority is the monopoly of the prosecutor. It is said in Latin is dominus litis or ruler of cases. This means that in the criminal process, the prosecutor is in charge of whether a case can be prosecuted to the court or not. ${ }^{5}$ With the authority possessed by the prosecutor to prosecute or not prosecute criminal cases to the court, in the prosecution tradition the principle of discretion is known which is divided into 2 (two) namely the prosecutor's authority to prosecute and the prosecutor's authority not to prosecute. ${ }^{6}$ In the prosecution of criminal cases, there are two principles that apply and are in opposite positions, namely the principle of legality which requires the prosecution of all cases to court and the principle of opportunity which gives the

${ }^{1}$ O Notohamidjojo, 2011, Soal-Soal Pokok Filsafat Hukum, Griya Media,Salatiga, p. 33.

${ }^{2}$ Ibid., p. 33-34.

${ }^{3}$ Kuat Puji Prayitno, 2011, Pengantar Ilmu Hukum (Kesenian Hukum dan Penemuan Hukum dalam Konteks Hukum Nasional), Kanwa Publisher, Yogyakarta, p. 2.

${ }^{4}$ L.J. van Apeldoorn, Pengantar Ilmu Hukum, Cet. 32, Pradnya Paramita, Jakarta, p. 13.

5 Bambang Waluyo, 2020, Penyelesaian Perkara Pidana, Penerapan Keadilan Restoratif dan Transformatif, Ed. 1, Sinar Grafika, Jakarta, p. 22.

${ }^{6}$ Ibid. 
Public Prosecutor the authority not to prosecute criminal cases in court. The authority to override cases in the public interest is the application of the principle of opportunity which is only owned by the Attorney General as regulated in Article 35 letter c of Act No. 16 of 2004 concerning the Attorney General's Office of the Republic of Indonesia, this is different from the termination of prosecution. The power to stop prosecution belongs to the Public Prosecutor. Termination of prosecution is regulated in Article 140 Paragraph (2) of the Criminal Procedure Code, which confirms that the public prosecutor "

The existence of a policy of stopping prosecution issued by the Attorney General of the Republic of Indonesia through the Regulation of the Attorney General of the Republic of Indonesia Number 15 of 2020 concerning Termination of Prosecution Based on Restorative Justice emphasizes that the Public Prosecutor is to stop a general criminal case whose conditions are to meet Article 5 Paragraph (1) of the Regulation of the Attorney General of the Republic of Indonesia Number 15 of 2020 concerning Termination of Prosecution Based on Restorative Justice: The suspect has committed a criminal act for the first time; Criminal acts are only threatened with a fine or are threatened with imprisonment of not more than 5 (five) years; and The crime is committed with the value of the evidence or the value of the loss caused as a result of the criminal act of not more than IDR $2,500,000,000.00$ (two million five hundred thousand rupiah). For crimes related to property,

The purpose of this research is to know and analyze effectiveness of cessation of prosecution based on restorative justice. To find out and analyze the process of termination of prosecution for termination based on restorative justice, it has met the requirements of the principles of restorative justice.

\section{Research Methods}

The approach method used in this research is a sociological juridical method (Sociological Research). ${ }^{7}$ The type of study in this research is more descriptive, namely providing data that is as accurate as possible about humans, circumstances or other symptoms. ${ }^{8}$ The sources and types of data in this study are secondary data obtained from library studies.

\section{Results and Discussion}

\subsection{Effectiveness of Dismissing Prosecution Based on Restorative Justice}

Efforts to eradicate criminal acts are carried out through the criminal justice system, namely the criminal justice system or the criminal justice system. ${ }^{9}$

\footnotetext{
${ }^{7}$ Amiruddin and Zainal Asikin, 2003, Pengantar Metode Penelitian Hukum, Raja Grafindo Persada, Jakarta,, p. 21

${ }^{8}$ Soerjono Soekanto, 1986, Pengantar Penelitian Hukum, Penerbit Universitas Indonesia, Jakarta, p. 10

${ }^{9}$ Rizky Adiyanzah Wicaksono and Sri Kusriyah, Implementation Of Restorative Justice Approach In Legal Protection Against Lightweight Crime By The Children, Jurnal Daulat Hukum Volume 1 Issue 4 December 2018 ISSN: 2614-560X, Unissula
} 
Termination of prosecution is carried out with a sense of justice, public interest, proportionality, criminal as a last resort, and fast, simple, and low cost. Closure for legal reasons is carried out in the event: the defendant dies; expiration of criminal prosecution; nebis in idem; a complaint for a criminal offense is withdrawn or withdrawn; or there has been a case settlement out of court for certain criminal acts, the maximum penalty is paid voluntarily in accordance with the provisions of the legislation or there has been a restoration of the original situation using a restorative justice approach.

Children are the smallest and most vulnerable part of society that is well placed with hope as the next civilization. Directly or indirectly in the child's social life interaction. While society as a social environment has a life of institutions/regulations/laws in order to regulate the pattern of relationships between people/people or people with their environment, which is intended to ensure order and minimize friction in the interactions that occur. ${ }^{10}$

A law enforcer in carrying out legal procedures for sanctions for children who are in conflict with the law or in this special situation, must use a special paradigm. This is very necessary because the sanctions given must be able to provide educational value, and the nature of the sanctions must be in accordance with the meaning of philosophy. Therefore, the sanction must provide the best solution to the existing problems, and in the best interests of the child, in accordance with the ultimum remidium principle. ${ }^{11}$

This happens because all cases, both big and small cases or serious and light cases, are all resolved through a judicial mechanism that leads to imprisonment, other alternatives of course need to be considered, such as the concept of restorative justice, in Indonesia this concept has been used in juvenile justice, for example, in dealing with cases of children by using diversion and the concept of restorative justice. ${ }^{12}$

Law enforcement is currently impressed, how to put criminals in prison, so that the perpetrators of criminal acts are all gathered in correctional institutions, the consequence is that prisons are full of convicts, even prisons are currently over capacity and become a major problem in prisons in Indonesia. ${ }^{13}$

The concept of the criminal justice system (criminal law) in the future must pay attention to the effectiveness and economic efficiency associated with criminal sanctions in the process of resolving a case. The concept of criminal law, which solely prioritizes punishment or retaliation, has slowly begun to be abandoned and has entered a new era or new phase, namely the renewal of the criminal law

\footnotetext{
${ }^{10}$ Adi Wibowo, Umar Maruf, Substantial Justice In Handling Of Child Actors "Klitih"Jurnal Daulat Hukum Volume 2 Issue 2, June 2019 ISSN: 2614-560X

${ }^{11}$ Rendy Surya Aditama, Umar Ma'ruf, Munsharif Abdul Chalim, Kebijakan Hukum Pidana Terhadap Anak Sebagai Pelaku Kejahatan Psikotropika Di Kepolisian Resor Magelang,Jurnal Daulat Hukum Vol. 1. No. 1 March 2018 ISSN: 2614-560X Unissula

${ }^{12}$ M. Musa, Peradilan Restoratif Suatu Pemikiran Alternatif System Peradilan Anak DiIndonesia, Www.Peradilanrestorative.Com.

13 Https://Www.Kompas .Com/Tren/ Read/ 2020/02/15/071700565/ OverKapasitasLapas-Masalah-Yang-Tak-Kunjung-Selesai-?Page=All.
} 
system that leads to legal protection for victims by providing compensation and providing a deterrent effect to perpetrators. ${ }^{14}$

The effectiveness of termination of prosecution based on Restorative Justice is carried out by taking into account the interests of the victims and other protected legal interests; avoidance of negative stigma; avoidance of retaliation; community response and harmony; and propriety, decency, and public order.

\subsection{The Dismissal Process for Dismissal Based on Restorative Justice Meets the Requirements of Restorative Justice Principles}

Restorative Justice or mediation of out-of-court settlements or the absence of due process, a form of means for enforcing laws that enforce justice for litigants. ${ }^{15}$ Children who commit crimes must be treated humanely in accordance with the best interests of the child, meaning that children in conflict with the law should have a restorative justice approach that should be pursued first. ${ }^{16}$

The primary goal of restorative justice is redress while the second goal is redress. With this concept, it can be interpreted that the process of law enforcement or overcoming criminal acts through a restorative approach is a process of resolving criminal acts that aims to restore the situation which includes compensation for victims through certain methods agreed by the parties involved. ${ }^{17}$

In tax cases, the concept of restorative justice is carried out with (1) the principles of restorative justice in law enforcement; and (2) the implementation of the principles of restorative justice in the enforcement of tax law in Indonesia, through tax collection efforts, tax audits, and investigations of criminal acts in the taxation sector. ${ }^{18}$

In Article 14 of the Criminal Procedure Code, the authority of the public prosecutor: to receive and examine the dossier of investigation cases from investigators, or assistant investigators; conduct pre-prosecution if there are deficiencies in the investigation by taking into account the provisions of Article 110 paragraph (3) and paragraph (4), by giving instructions in the context of completing the investigation from the investigator; grant an extension of detention, carry out further detention or detention and or change the status of the detainee after the case has been delegated by the investigator; make an indictment; delegate the case to the court; deliver notification to the defendant regarding the provisions on the day and time the case will be heard accompanied by a summons, both to the defendant and to witnesses, to come at the hearing that has been determined;

\footnotetext{
${ }^{14}$ Novita Sari, 2017, Penerapan Asas Ultimum Remedium dalam Penegakan Hukum Tindak Pidana Penyalahgunaan Narkotika. De Jure, 3(3): 353.

15Ragil Tri Wibowo and Akhmad Khisni, Restorative Justice in Application for Crime Investigation on Property, Jurnal Daulat Hukum Volume 1 No. 2 June 2018 ISSN: 2614-560X, Unissula

${ }^{16}$ Saepudin, Umar Ma'ruf,Completion Of Diversion As A Form Of Child Through Criminal Investigators By Restorative Justice Approach In Police Office Of Indramayu,Jurnal Daulat Hukum Volume 1 Issue 2, June 2018 ISSN: 2614-560X, Unissula

${ }^{17}$ Rufinus Hotmaulana Hutauruk, 2013, Penanggulangan Kejahatan Korporasi MelaluiPendekatan Restoratif Suatu Terobosan, Sinar Grafika, Jakarta, p. 107.

18Sarwirini, Implementasi Restorative Justice Dalam Penegakan Hukum Pajak, Yuridika, Volume 29 No 3, September-December 2014, p. 384.
} 
carry out prosecutions; closing the case for the sake of law; take other actions within the scope of duties and responsibilities as a public prosecutor according to the provisions of this law; carry out the judge's decision.

Termination of prosecution for policy reasons, where the prosecutor is allowed to put aside the case even though there is sufficient evidence to be submitted to the court for the public interest or individual interests and is based on unwritten law (opportunity principle). Based on article 77 of the Criminal Procedure Code, the Attorney General has the authority to overrule cases, where the case side action consists of: 19 setting aside cases on the principle of opportunity, setting aside cases on the basis of a criminal law assessment, setting aside cases on the basis of legal interests, as stated in the Circular Letter of the Attorney General of the Republic of Indonesia Number SE-001/JA/4/1995 dated 27 April 1995 concerning Guidelines for Criminal Prosecutions, among others regarding instructions for termination of conditional criminal charges.

The process of discontinuing the prosecution of termination based on restorative justice has met the requirements of the principles of restorative justice, namely: The Public Prosecutor offers peace efforts to the Victim and the Suspect. The Public Prosecutor shall summon the Victim legally and properly by stating the reasons for the summons. In the event that it is deemed necessary, peace efforts may involve the families of the Victim/Suspect, community leaders or representatives, and other related parties.

\section{Closing}

The effectiveness of termination of prosecution based on Restorative Justice is carried out by taking into account the interests of the victims and other protected legal interests; avoidance of negative stigma; avoidance of retaliation; community response and harmony; and propriety, decency, and public order. The process of terminating prosecution based on restorative justice has met the requirements of the principle of restorative justice, namely that the Public Prosecutor offers peace efforts to the Victim and the Suspect, the Public Prosecutor makes a legal and proper summons to the Victim by stating the reasons for the summons. In the event that it is deemed necessary, peace efforts may involve the families of the Victim/Suspect, community leaders or representatives, and other related parties. The Public Prosecutor shall notify the aims and objectives as well as the rights and obligations of the Victims and Suspects in peace efforts, including the right to refuse peace efforts. In the event that the peace effort is accepted by the Victim and the Suspect, the peace process will be continued. It is recommended that every criminal case process with a threat of less than 5 (five) years and a loss of less than IDR 2,500,000.00 (two million five hundred thousand rupiah) and efforts to make peace between the two parties must first be attempted to be resolved with restorative justice efforts as stipulated in the law. Prosecutors' Regulation of the Republic of Indonesia Number 15 of 2020 concerning Termination of Prosecution Based on Restorative Justice so that the legal

\footnotetext{
${ }^{19}$ Hendi Suhendi, 1984, Penerapan Asas Opportunitas Dalam Penegakan Hukum (Suatu Tinjauan Yuridis Dan Sosiologis), Sebagaimana Disebutkan Dalam Andi Hamzah, Bunga RampaiHukum Pidana Dan Acara Pidana, Ghalia Indonesia, Jakarta, p. 154-156.
} 
objectives of upholding justice, obtaining legal certainty and obtaining benefits can be immediately achieved and realized without having to fill prisons in Detention Centers and Correctional Institutions.

\section{References}

\section{Journal}

[1] Adi Wibowo, Umar Maruf, Substantial Justice In Handling Of Child Actors "Klitih" Jurnal Daulat Hukum Volume 2 Issue 2, June 2019 ISSN: 2614-560X, Unissula

[2] Ragil Tri Wibowo and Akhmad Khisni, Restorative Justice in Application for Crime Investigation on Property, Jurnal Daulat Hukum Volume 1 No. 2 June 2018 ISSN: 2614-560X, Unissula

[3] Rendy Surya Aditama, Umar Ma'ruf, Munsharif Abdul Chalim, Kebijakan Hukum Pidana Terhadap Anak Sebagai Pelaku Kejahatan Psikotropika Di Kepolisian Resor Magelang, Jurnal Daulat Hukum Vol. 1. No. 1 March 2018 ISSN: 2614-560X Unissula

[4] Rizky Adiyanzah Wicaksono and Sri Kusriyah, Implementation Of Restorative Justice Approach In Legal Protection Against Lightweight Crime By The Children, Jurnal Daulat Hukum Volume 1 Issue 4 December 2018 ISSN: 2614-560X, Unissula

[5] Saepudin, Umar Ma'ruf, Completion Of Diversion As A Form Of Child Through Criminal Investigators By Restorative Justice Approach In Police Office Of Indramayu, Jurnal Daulat Hukum Volume 1 Issue 2, June 2018 ISSN: 2614-560X, Unissula

[6] Sarwirini, Implementasi Restorative Justice Dalam Penegakan Hukum Pajak, Yuridika, Volume 29 No 3, September-December 2014

\section{Book}

[1] Amuruddin dan Zainal Asikin, 2003, Pengantar Metode Penelitian Hukum, Raja Grafindo Persada, Jakarta

[2] Bambang Waluyo, 2020, Penyelesaian Perkara Pidana, Penerapan Keadilan Restoratif dan Transformatif, Ed. 1, Sinar Grafika, Jakarta

[3] Hendi Suhendi, 1984, Penerapan Asas Opportunitas Dalam Penegakan Hukum (Suatu Tinjauan Yuridis Dan Sosiologis), Sebagaimana Disebutkan Dalam Andi Hamzah, Bunga Rampai Hukum Pidana Dan Acara Pidana, Ghalia Indonesia, Jakarta

[4] Kuat Puji Prayitno, 2011, Pengantar Ilmu Hukum (Kesenian Hukum dan Penemuan Hukum dalam Konteks Hukum Nasional), Kanwa Publisher, Yogyakarta

[5] L.J. van Apeldoorn, Pengantar Ilmu Hukum, Cet. 32, Pradnya Paramita, Jakarta,

[6] Novita Sari, 2017, Penerapan Asas Ultimum Remedium dalam Penegakan Hukum Tindak Pidana Penyalahgunaan Narkotika. De Jure, 3(3)

Notohamidjojo, 2011, Soal-Soal Pokok Filsafat Hukum, Griya Media, Salatiga,

[7] Rufinus Hotmaulana Hutauruk, 2013, Penanggulangan Kejahatan Korporasi Melalui Pendekatan Restoratif Suatu Terobosan, Sinar Grafika, Jakarta, 
[8] Soerjono Soekanto, 1986, Pengantar Penelitian Hukum, Penerbit Universitas Indonesia, Jakarta

\section{Internet}

[1] Https://Www.Kompas .Com/Tren/ Read/ 2020/02/15/071700565/ OverKapasitasLapas-Masalah-Yang-Tak-Kunjung-Selesai-?Page=All

[2] M. Musa, Peradilan Restoratif Suatu Pemikiran Alternatif System Peradilan Anak Di Indonesia, Www.Peradilanrestorative.Com 